\title{
Alexander of Cotiaeum Teacher, Exegete, Diorthotes
}

\author{
Fausto Montana \\ Università di Pavia \\ fausto.montana@unipv.it
}

\begin{abstract}
Alexander of Cotiaeum, the cultivated sophistes and one among the teachers of Aelius Aristides and Marcus Aurelius, distinguished himself in linguistic and literary studies, teaching, and cultural communication. Though without achieving brilliant results, he also engaged in some of the questions previously discussed by the most learned scholars. This cultural figure displays some typicality with respect to the average educated personalities (grammatikoi) of the Antonine renaissance. However, current studies are revealing a possible specificity of Alexander's role: his influence, by way of educational approach, on the making of literary trends and models (canons) of the concurrent high culture, between New Sophistic and Atticism. This paper focuses on the very philological side (diorthosis, or textual criticism) of the composite and complex intellectual profile of Alexander.
\end{abstract}

\section{Keywords}

Alexander of Cotiaeum - Teaching - Exegesis - Textual criticism - Graeco-Roman culture

The figure of the grammatikos Alexander of Cotiaeum is highly considered in modern studies, compared to other similar ('minor') personalities of the Graeco-Roman culture in the first centuries of the Empire. This fame is especially due to the good personal relations maintained by Alexander, as teacher of grammar and literature, with two outstanding students, the young Aelius Aristides and the future Emperor Marcus Aurelius. ${ }^{1}$ In recent times, while the attention towards Alexander has continued to be developped within the

1 For example: Sandys 1921³ , 312; Boulanger 1923; Behr 1968 and 1981-1986; Cortés Copete 1995. 
context of the studies on his two eminent disciples, at the same time his personality and his work have been the object of a specific critical interest and have been finding an autonomous place in the historiographic reconstruction of the literary and rhetoric culture of the Antonine Age. As to the first aspect, the crucial step towards a specific interest for Alexander is represented by the critical edition of the testimonies and surviving fragments of his work edited by Andrew R. Dyck in 1991, and integrated in 1998 by Klaus Alpers with the addition of four other fragments. ${ }^{2}$ With regard to the second aspect, that is considering the grammatikos within the historical context of his time and finding his specific cultural contribution, important acquisitions have been obtained thanks to the enquiries by Jean-Luc Vix, Laurent Pernot and Elisabetta Berardi devoted to grammatical and rhetorical teaching in the II century AD. ${ }^{3}$ If we wanted to get a snapshot of Alexander's historiografical profile coming out from these studies, we might reconstruct a learned and therefore admired personality, a $\gamma p \alpha \mu \mu \alpha \tau i x o ̀ \varsigma ~ \pi \circ \lambda \nu \mu \alpha \theta \varepsilon \dot{\sigma} \sigma \alpha \tau \tau \varsigma$, as defined by Stephanus of Byzantium, ${ }^{4}$ who expressed his best talents in linguistic and literary studies, in teaching and cultural communication, without refraining from competing with the most learned and authoritative philological and exegetical tradition, though without achieving quite brilliant results. ${ }^{5}$ Even if Alexander's exceptional connections have determined or at least greatly favoured his reputation both in ancient and modern times, we can go as far as seeing him as a typical figure representing the most educated class of grammatikoi of the Antonine renaissance. However, the most recent investigations are also revealing his specificity in the influence he probably had on the making of linguistic-literary trends and models or canons of outstanding representatives of the coeval high culture, between New Sophistic and Atticism. As a matter of fact, we can argue that Alexander was an exponent of the cultural 'underworld' in the period of great ferment between the reigns of Hadrian and Marcus Aurelius, whose impulses from below contributed to shaping and substantiating the features of other, high culture figures - that is, of figures who, later on, established themselves in cultural history and historiography with the standing and weight of absolute protagonists. ${ }^{6}$ This paper will focus on well-documented aspects of Alexander's multifaceted activity which seem to confirm this interpretation.

2 Dyck 1991; Alpers 1998.

3 Vix 2004 and 2010; Pernot 2008; Berardi 2002, 2013 and 2016.

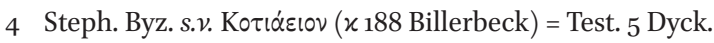

5 For this opinion cf. Dyck 1991, 333-335; Alpers 1998, 102; Matthaios 2015, 239. Much more laudatory Vix 2004, 369-372.

6 A thorough and non-prejudicial study of the biographical and intellectual circumstances concerning the ancient scholars can help overcome the traditional historiographic dichotomy, 
I think it would be useful, first of all, to recall Alexander's biographical data and composite intellectual portrait; and to highlight both the ordinary side of his profile and the distinctive qualities that we recognize as influential and fecundating for his historical milieu. ${ }^{7}$ Native of the Phrygian city of

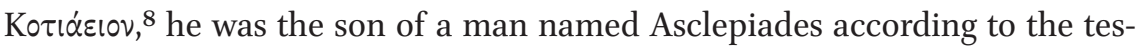
timony of Stephanus of Byzantium and of the Etymologicum Genuinum. ${ }^{9}$ The chief and generous source for his biographical and cultural profile is the epitaph pronounced in his honour by Aelius Aristides, who had been his disciple. ${ }^{10}$ Aristides' own biography and the dating of the epitaph from the year $150 \mathrm{AD}$ provide the essential coordinates for Alexander's lifetime: he was probably born between 70 and $80 \mathrm{AD}$ and died in $150 .{ }^{11} \mathrm{He}$ lived in Rome, where he engaged in a successful and prestigious activity of remunerated teaching, which enabled him to amass a huge fortune and be well known in the intellectual landscape of the capital. Antoninus Pius chose him as tutor of his adoptive sons Lucius Verus and Marcus Aurelius. The latter, at the beginning of his Thoughts, recalls with affectionate admiration Alexander's human qualities and his valuable teaching. ${ }^{12}$ From Aristides' oration we learn that the city of Cotiaeum paid tribute to him posthumously, as a reward for the intense mediation he had conducted at the imperial court, as well as for his evergetism to the homeland.

Aristides addresses his epitaph in the form of an epistolary consolatio $\tau \hat{\eta}$

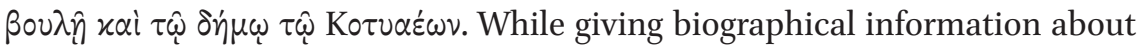
Alexander, he depicts his intellectual portrait in encomiastic terms. Alexander

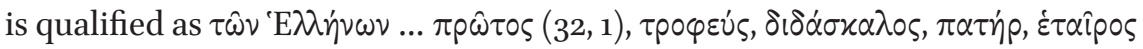

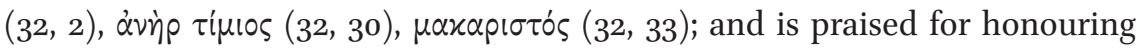
Cotiaeum by associating its name to his own 'in the books he submitted to

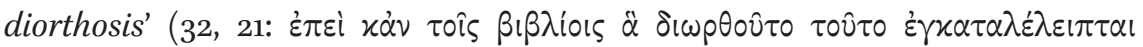

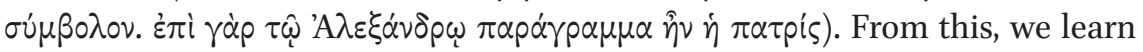

so comfortable but often arbitrary, between 'major' and 'minor' figures: cf. Montana 2015, $67-68$, with regard to the history of Hellenistic scholarship.

7 The essential data, texts and bibliography are available in Montana 2018a; cf. Wentzel 1894; Montanari 1996.

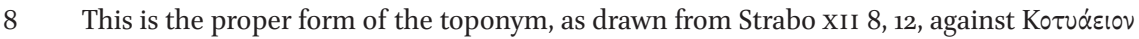

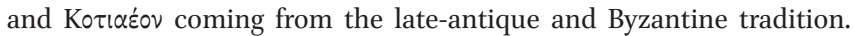

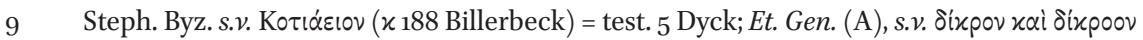
$=$ fr. 4 Dyck.

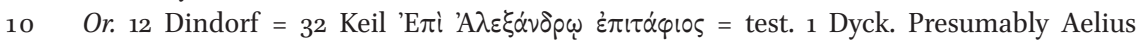
Aristides listenend to Alexander's lessons in his own home town, Smyrna. Boulanger 1923, 114, thinks, instead, that Aristides went expressly to Cotiaeum.

11 For dating: Behr 1968, 51 and 76; Vix 2010, 65-66.

12 M. Aur. 1, 10 = test. 2 Dyck; cf. Hist. Aug. Aur. 2, 3 = test. 3 Dyck. Pernot 2008. 
that Alexander - rather than preparing real new editions of ancient writings made textual analyses and amendments on the works he used for teaching, and authenticated the copies he had corrected by affixing a subscriptio. Moreover Aristides documents that Alexander's competences concerned both poetry and prose and resulted in masterful oral teachings more than (or rather than) in writings. Aristides provides a sort of canon, admittedly not exhaustive, of the authors Alexander was used to explain and comment on (cf. 32, 24, where

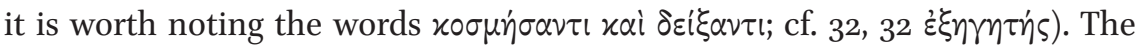
list expressly includes Homer, Archilochus, Hesiod, Simonides, Stesichorus, Pindar, Sappho and Alcaeus, and intentionally overlooks Attic authors, whose

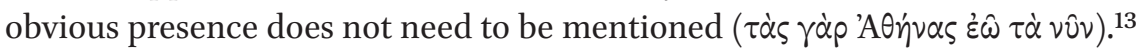
A little further, Aristides praises Alexander's acquaintance with Plato's works $(32,25, \mathrm{cf} .32,34)$ and mentions an Ai $\sigma \omega \dot{\omega} \pi 0 v \pi \rho \hat{\alpha} \gamma \mu \alpha(32,27)$, whose nature is unknown to us - unless supposing with Cortés Copete that the paraphrase and the explanation of Aesop's fables may represent the first step in the grammatikos'teaching on poets. ${ }^{14}$

Apart from the magniloquent style of the encomium and from the emphasis on the high level of Alexander's qualities, the wealth of competences and activities reported by Aristides do not appear, as a whole, very far from the expected model of grammatikos according to the Greek educational curriculum, concerning higher education performed through reading of and comment on literary texts. ${ }^{15}$ We are going to examine first these 'ordinary' aspects of Alexander's activity. The main professional practice is the reading of authors and works of the long-established canon, resulting from the erudite work performed by generations of scholars, especially the Alexandrian ones, since the Hellenistic Age and, under the impulsion of different intellectual suggestions, again in the days of Alexander. The areas of education include epics and lyric poetry and the fundamental Attic literature. Prose is not absent and in this field Aristides puts emphasis on Plato, as master of thought and of Attic

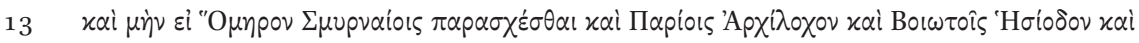

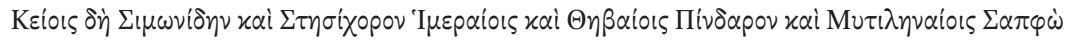

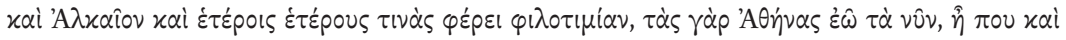

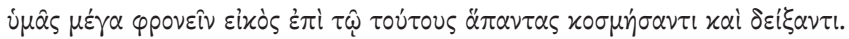

14 Cortés Copete 1995, 174-175 n. 20. It is worth noting that, according to an ancient tradition,

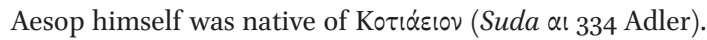

15 The choice of Greek authors read by Alexander according to the testimony of Aelius Aristides is comparable, for instance, with the canon attested by Papinius Statius for his father, emphatically commemorated as a successful poet, esteemed teacher and exegete of Homer, Hesiod, Epicharmus, Pindar, Ibycus, Alcman, Stesichorus, Sappho, Callimachus, Lycophron, Sophron, Corinna (Stat., Silv. V 3, 146-158). I am grateful to Giancarlo Abbamonte for suggesting this comparison. 
language. Alexander's specificity that we can infer in this field from Aristides' encomium appears not so much related to the identity of the authors read by the teacher, but rather to the extension of the programme conducted by him in his courses.

Reading means explanation, therefore essentially literary exegesis including linguistic analysis, observations on morphology and interpretation of the content. It is evident from Aristides' words that it was a professional practice mainly conducted on the plan of oral communication in the classroom. However, these are in fact the fields represented by most of the about twenty surviving fragments of Alexander's writings, ${ }^{16}$ as can be illustrated by the analysis of a sample. Three fragments of etymological content are explicitly connected by

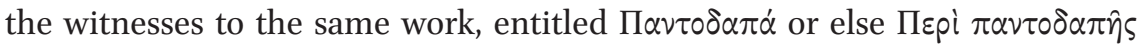

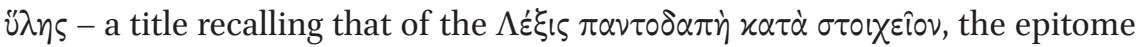
in 5 books of Pamphilus' great lexicon produced by Diogenianus, ${ }^{17}$ who was probably a younger contemporary of Alexander. According to Stephanus of

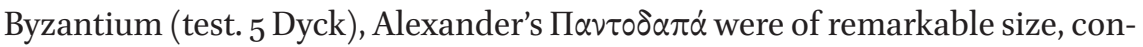
sisting of 24 books. One of the fragments (16 Alpers) discusses the etymology

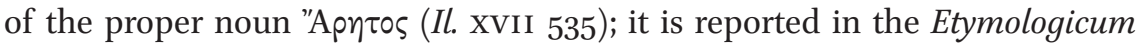
Genuinum and from there repeated in the posterior etymological works. We learn from the witnesses that Alexander drew the etymology on Cratinus, a grammarian about whom we only know that he had realized an epitome of

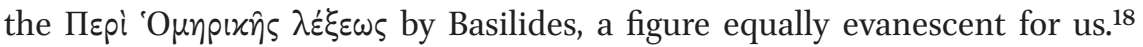
However, our lack of information does not prevent us from appreciating two

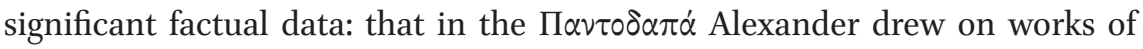
specialized lexicography; and that his collection was taken into consideration by later compilers as a vehicle, clearly considered reliable, of the lexicographical and etymological tradition. The other two fragments expressly referred

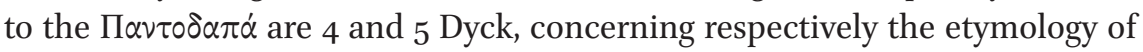

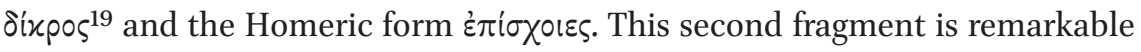

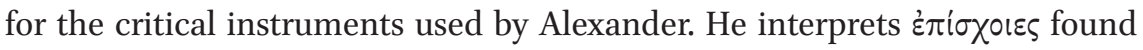
in Il. XIV 241 as second person singular optative, written with epsilon in the inflection and with accent retraction, instead of $\dot{\pi} \pi \sigma x o i n s$, and he explains

\footnotetext{
16 Cf. Vix 2004, 364.

17 For the title: Suda $\delta 1140$ Adler.

18 About these two grammarians: Meliadò 2018 (Basilides) and Meliadò forthcoming (Cratinus).

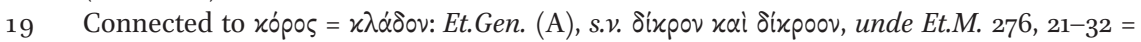

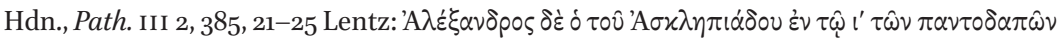
$\pi \alpha p \dot{\alpha}$ tò xópos, ö $\chi \lambda \alpha \dot{\delta} 0$ เ $\sigma \alpha p \circ \hat{v}$. On this fragment cf. Vix 2004, 365-366.
} 
it as a transliteration error occurred when shifting to the Attic vowel system

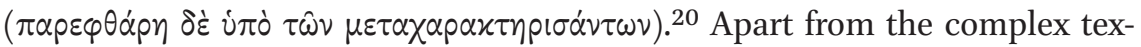
tual issue, and therefore from the plausibility of the solution suggested by Alexander, ${ }^{21}$ here it is interesting to stress that the argument, based on the knowledge of a datum of phonetics and of the history of language and writing, draws once again on specialist proficiency. ${ }^{22}$ Therefore the П $\alpha \nu \tau 0 \delta \alpha \pi \dot{\alpha}$ were probably an etymological lexicon, far from being elementary. The fact that two lemmas, starting respectively with $\delta$ and $\varepsilon$, come from the same book of the collection rightly leads Dyck to suppose that the lexicon was organized in alphabetical order. ${ }^{23}$ I would also argue that the book in question, the tenth, is congruent with an alphabetical sylloge comprising 24 books.

It is quite probable that the other etymological remarks attributed to Alexander in the sources, ${ }^{24}$ which essentially concern Homeric words, also

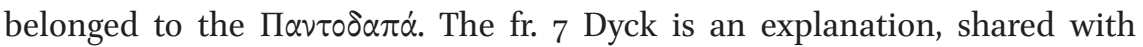

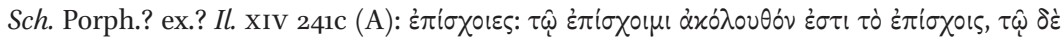

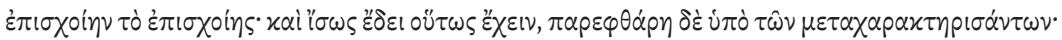

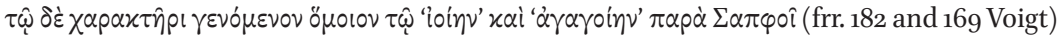

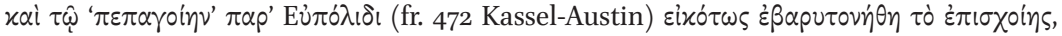

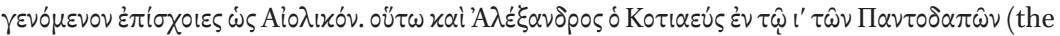
connection of the scholium with Porphyry, argued by Erbse 1960, 97-98, is questioned by

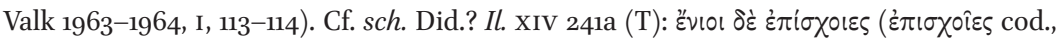
corr. Erbse). According to sch. Hrd. Il. XIV 241b ${ }^{1}$ (A), also Herodian (I, 469, 14 Lentz) read $\dot{\varepsilon} \pi i \sigma \chi 0 ı \varepsilon$, but he explained it as a form derived either from $\dot{\varepsilon} \pi i \sigma \chi 0 ı$ by adding $\varepsilon$, or from $\varepsilon \dot{\pi} / \sigma \chi$ oins by shortening $\eta$.

21 Alexander's correction $\dot{\varepsilon} \pi \mid \sigma \times$ in $_{5}$, which is prevailing in the medieval paradosis (and is included in Hesychius' Lexicon, $\varepsilon 5^{284}$ Latte), is the reading also preferred by the modern critical editors of the Iliad (e.g. Dindorf, Monro-Allen, Allen in the ed. maior, van Thiel) and is considered plausible by Chantraine 1958, 464; Valk 1963-1964, II, 215 with n. 590; Janko 1991, 189. Instead West 2000 chooses $\dot{\varepsilon} \pi \dot{\sigma} \sigma 01 \alpha \varsigma$, a reading sporadically documented

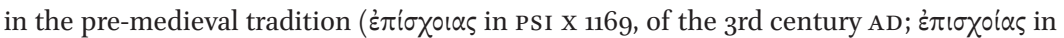
Bibl. Brit. Add. MS. 17210, of the 6th century), in the footsteps of Wackernagel 1897, 45-46 (= Kleine Schriften, I, 806-807) and 1916, 14 and 16 (but already 1878, $272=$ Kleine Schriften,

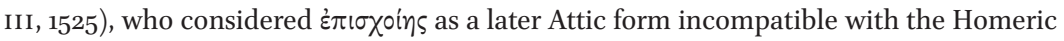
morphology; cf. Schulze apud Premerstein 1909, 259 (= Schulze 1934, 404); Schwyzer 1939, 660 with n. 7 .

The ancient exegetes were well aware of the text alterations that could be derived from the metacharacterismos, at least starting from Aristarchus: sch. Ariston. Il. XI 104a ${ }^{1}$. Cf. Dyck 1991, 319. Alexander's interest in the morphological and lexical observation is also witnessed by Georgius Choeroboscus (frr. 10a Dyck, cf. fr. 10b Dyck), who attributes to him the theory of the formation of verbs with the present indicative ending with $-\chi \omega$ and $-\chi \omega$ from sigmatic futures, such as for instance $\sigma \mu \eta \dot{\eta} \chi \omega$ from $\sigma \mu \hat{\omega} \sigma \mu \eta \dot{\eta} \sigma \omega, \quad \partial \lambda \dot{\varepsilon} \kappa \omega$ from $\dot{\partial} \lambda \hat{\omega} \dot{\partial} \lambda \dot{\varepsilon} \sigma \omega$ (on fr. 10 Dyck cf. also Vix 2004, 366-367).

23 Dyck 1991, 318.

24 Frr. 9-14 Dyck and frr. 17-19 Alpers. Cf. Dyck 1991, 324; Alpers 1998, 98 and 100. 
Didymus Chalcenterus, of the metaphorical meaning of the syntagm $\dot{\alpha} \mu \dot{\alpha} \tau \varepsilon 10 v$

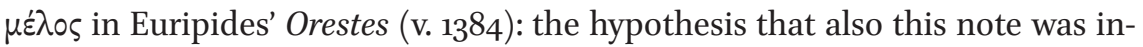

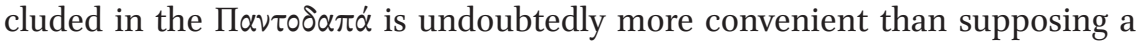
specific work on the tragedian, that is not attested. As to fr. 6 Dyck, concernig a variety of the vine plant named $\alpha \mu \alpha \mu \alpha \xi \dot{v} \varsigma$, Alpers thinks that it is not to be attributed to Alexander of Cotiaeum, arguing that it should rather be attributed to the Polyhistor, on the basis of the content and of traditional reasons: the source, an entry of the Etymologicum Magnum, thanks to the comparison with Hesychius, is to be traced back, through Diogenianus, to Pamphilus' lexicon, therefore to a source preceding the times of Alexander of Cotiaeum. ${ }^{25}$ Instead the gateway to Alexander's etymologies in Byzantine lexicography is to be found in Oros, the grammarian of the $5^{\text {th }}$ century, thanks again to a tes-

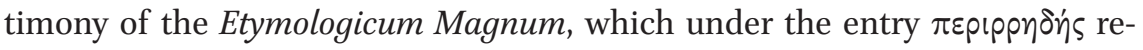
ports the explanations of Alexander and Pius and mentions Oros as its source

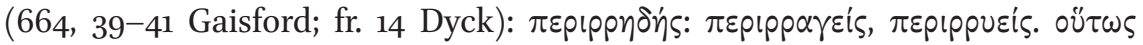

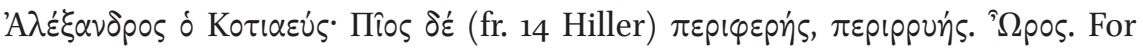
the period prior to Oros, a possible step in the reception of Alexander's lexical

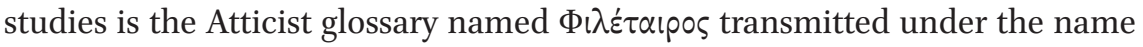
of Herodian ${ }^{26}$ and edited by Alphonse Dain: ${ }^{27}$ accepting a hypothesis advanced by Reitzenstein, ${ }^{28}$ Alpers suggested to recognize the $\Phi_{l} \lambda \dot{\varepsilon} \tau \alpha l \rho \circ \varsigma$ as a 3 rd century excerptum of an Atticist writing composed by Alexander. ${ }^{29}$ Another early hypothesis, recently resumed by Elisabetta Berardi with new arguments, supposes that the fortune of Alexander's lexicography may have been supported by the active appreciation of Phrynichus the Atticist: there is no positive evidence of a relationship between them, but it can actually be inferred from Phrynichus' close connections with Aelius Aristides and with Cornelianus, the secretary ab epistulis of Marcus Aurelius and dedicatee of the Eclogue. ${ }^{30}$

So, this thin and frayed network of documented or plausible relations of lexicographical traditions and of personalities allows to guess that Alexander had high quality learned and intellectual acquaintances and knowledge. This eloquent teacher, vigorously praised by Aristides as a brilliant reader and oral commentator of classics, and remembered by Marcus Aurelius for the polite sense of tolerance he showed towards those who, in his presence,

\footnotetext{
25 Alpers 1998, 100-102.

26 On this attribution see Dyck 1993, 791-792.

27 Dain 1954.

28 Reitzenstein 1897, 389 .

29 Alpers 1998, 107-108; cf. Berardi 2016, 260-261.

30 Naechster 1908, 85-87; Boulanger 1923, 411; Berardi 2016, 250, 258-262. In general on Phrynichus as a source of Oros: Tosi 1984, 182 and 186-187.
} 
used barbarisms and solecisms, thanks to his lexical studies consigned to the $\Pi \alpha \nu \tau 0 \delta \alpha \pi \alpha$ was highly considered for centuries, between Late Antiquity and the Byzantine Age, by the compilers of etymological sylloges; and, quite unexpectedly, he might even have had an influence on Phrynichus, the austere prophet and guardian of the most intransigent Atticism.

Furthermore, there are repeated positive testimonies of the consideration and fortune also enjoyed by Alexander's exegesis of literary contents in 'upstairs' of learned culture. At least five of his explanations of passages of the Iliad are endorsed by Porphyry in his 'O $\mu \eta p$ Homeric scholia that might be traced back to Porphyry. ${ }^{31}$ In introducing one of these fragments, dedicated to the explanation of a scene depicted on the shield of Achilles, ${ }^{32}$ Porphyry says expressly that it is drawn on Alexander's 'E $\xi \eta \gamma \eta \tau i x \alpha$, in at least two books, that are probably to be identified with the

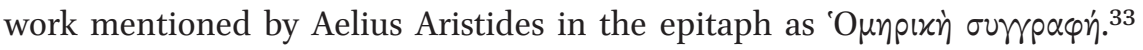
Two other fragments of Alexander's Homeric exegesis transmitted among the scholia of the Venetus A manuscript of the Iliad are likely to come from this work; they concern respectively the meaning of the metaphor of the "knot of

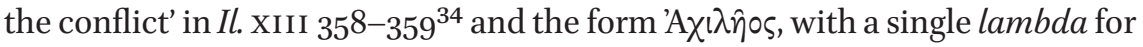
metrical reasons, in the first verse of the poem. ${ }^{35}$

To make an assessment of this quick review on the 'conventional' side of Alexander's activity, we can recognize in what remains of the П $\alpha \nu \tau 0 \delta \alpha \pi \alpha$ and of the 'E $\xi \eta \gamma \eta \tau \ltimes \dot{\alpha}$ the traces, shall we say, of an intermediate socio-cultural condition between school and scholarship, between the tasks of oral didaxis and written erudite memory. The П $\alpha \nu \tau o \delta \alpha \pi \dot{\alpha}$ appear to us as the product of linguistic-etymological skills presumably exerted in school teaching and, at the same time, applied to matters and with methods not free from some philological ambition and sophistication - as, for instance, the consideration of problems

31 Frr. 1-3ab, 5 and 8 Dyck. Cf. Erbse 1960, 53-55 and 96-98; contra Valk 1963-1964, I, 113-114 (cf. supra, with regard to sch. Il. XIV 241c = fr. 5 Dyck).

32 Il. XVIII 509ff.; test. 6 = fr. 2 Dyck. On the passage, see Vix 2004, 367-369.

33 Test. 4 Dyck; cf. Lehrs 1837, 11. On the 'E $\xi \eta \curlyvee \eta \tau \iota x \alpha$, see Erbse 1960, 53-56. This title might

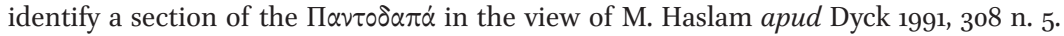

34 Fr. 1 Dyck $=$ sch. Porph.? Il. XIII 358-359 (A). As to the traditional path followed by these fragments to be conveyed to the Venetus A manuscript, either through Porphyry or through other channels (for example the scholia exegetica: Dyck 1991, 320 with n. 34), a clue supporting the hypothesis of Porphyry is the fr. 3 ab Dyck (on the posture of Achilles and Agamemnon during their speeches at the Achaean assembly in Il. XIX 79ff.), trans-

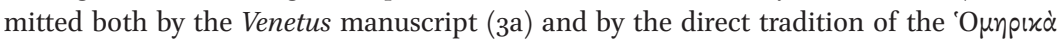
$\zeta \eta \tau \dot{\eta} \mu \alpha \tau \alpha$ (3a: Porph. ad Il. I 234, 10 Schrader = 112, 7 Sodano).

35 Fr. 8 Dyck $=s c h$. Porph.? Il. I $1^{\mathrm{i}}\left(\mathrm{A}^{\mathrm{im}}\right)$ : the form 'A $\chi \chi \lambda \hat{\eta}$ os is justified by the same metrical

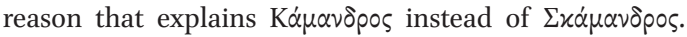


of writing, copy and transmission of literary texts in fr. 5 Dyck. These concepts and categories were particularly stimulating for the rising stars of Atticism and New Sophistic in the Antonine Age. Indeed, in the light of the hypotheses of personal and intellectual connections mentioned above, it cannot be excluded that the vedettes of high culture had become aware of this type of concepts just thanks to their relations with learned teachers like Alexander. Likewise, in the 'E $\xi \eta \gamma \eta \tau i x \alpha$ he had to take advantage of the lively routine experience of school explanation, so praised by Aristides, without renouncing to dialogue and compete with the specialized and professional exegesis that, later on, selected and coopted some of his interpretations. It is undoubtedly in the field of teaching, in its development and in relation to it, that Alexander met opportunities to also perform text diorthosis; and with sufficient frequency, to induce Aristides to record this activity among the stable and qualifying features of the cultural

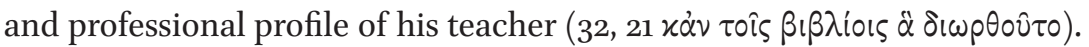

On Alexander's diorthotic attitude, which appears as the less common aspect of his activity, it is worth paying greater attention. By a rare stroke of luck, Aristides' generic testimony on Alexander's habit to amend the literary texts he used for his lessons is supported and exemplified by a specific case well documented by Porphyry. The eighth question of the first book of the 'O $\zeta \eta \tau \eta^{\prime} \mu \alpha \tau \alpha$ dwells on the problems posed by the diorthosis of the Homeric text, in particular with regard to the impact of corruption on the text quality of the poems. Porphyry considers instructive to make a comparison with a different but in his view parallel field, that is, the tradition of the writings of Greek historians; and he reports as an example a long extract from an erudite

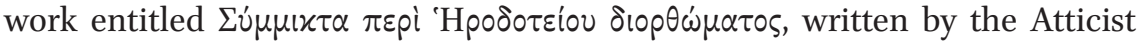
lexicographer Philemon, active around $200 \mathrm{AD}$, therefore half a century after Alexander's death. ${ }^{36}$ It is worth reporting Porphyry's passage here below (286, 19ff. Schrader $=35$, gff. Sodano).

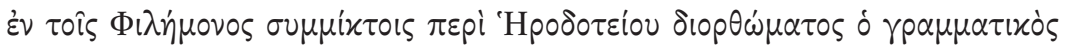

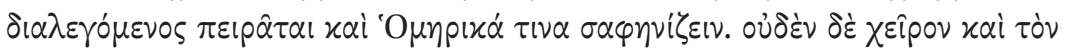

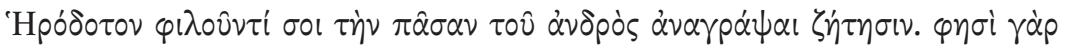

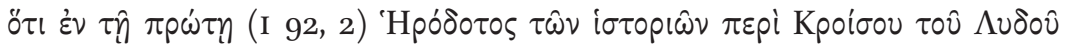

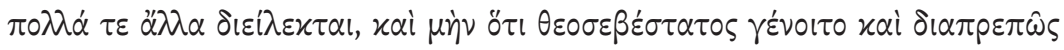

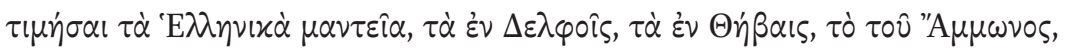

36 Philemon's lexicographical fragments are edited by Reitzenstein 1897, 392-396; Cohn 1898. For the identification of the author of the $\Sigma \dot{v} \mu \mu \varkappa \tau \tau \alpha$ with the Atticist: Cohn 1898, 363-366. Recent overview in Ucciardello 2007. For a sketch of the erudite reading of Herodotus in the Hellenistic and Roman Ages, see Montana 2018b, 17-30. 


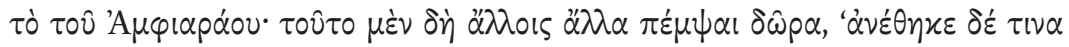

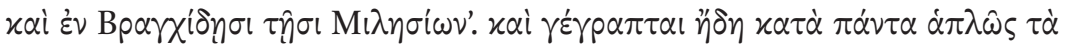

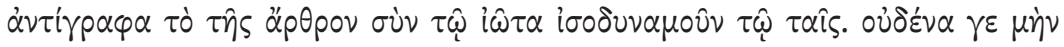

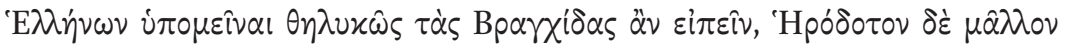

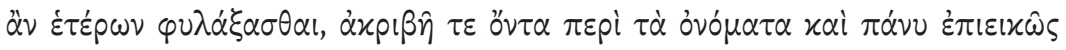

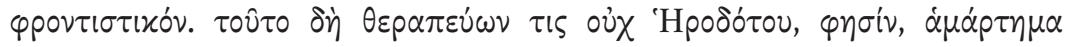

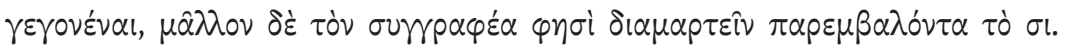

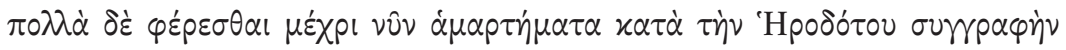

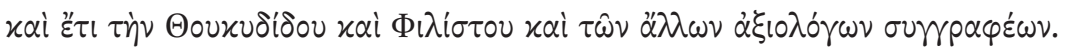

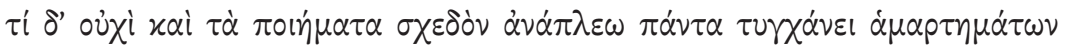

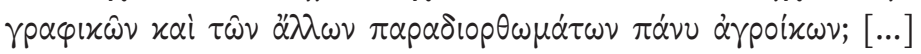

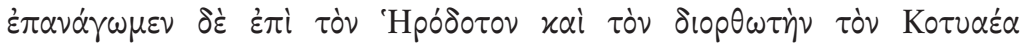

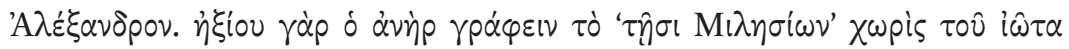

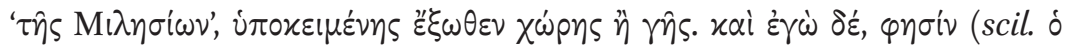

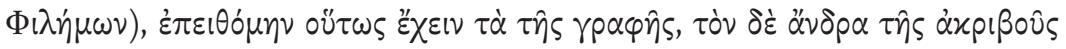

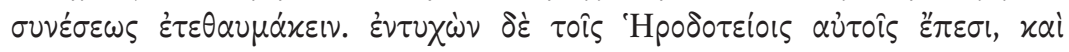

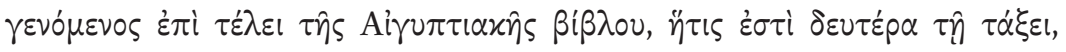

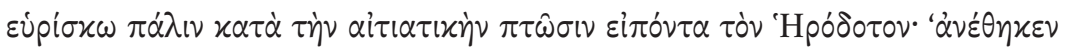

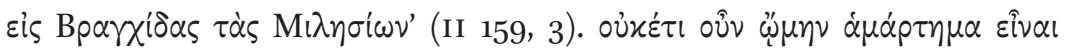

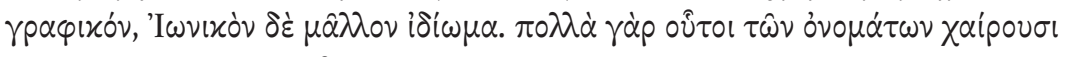

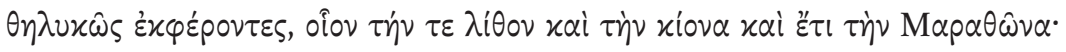

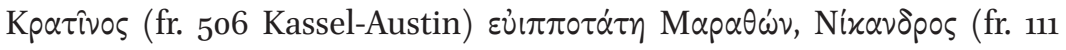

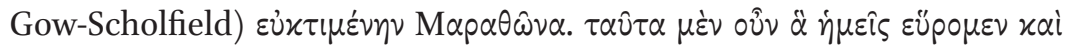

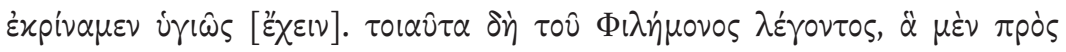

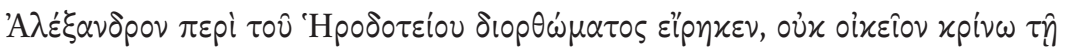

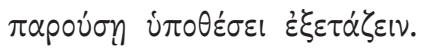

'During his discussion of an emendation in Herodotus in his Miscellanea, Philemon the Grammarian attempts to clarify certain points in Homer as well. Since you are also fond of Herodotus, it will be none the worse if I record for you the whole of the scholar's investigation. He says that in Book I (92) of the Histories, Herodotus narrated many things about the Lydian, Croesus, among them that he was very pious and that he had magnificently endowed the oracles of the Greeks at Delphi and Thebes as well as those of Ammon and Amphiareus: «for this reason, he sent various gifts to various places and also made some dedications in Branchidai of

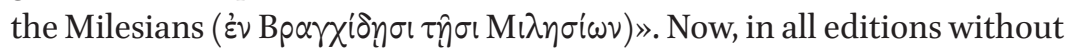
exception, the article $\tau \hat{\jmath} \varsigma$ was written with an iota, making it the equivalent of $\tau$ «î (dative plural, feminine). No Greek, however, would have said that Branchidai can be feminine, he says, and Herodotus would be 
more on his guard than others since he was precise and extremely careful with names. «Mindful of this», (Philemon) says, «someone (explained) that the error was not Herodotus' but rather that a scribe erred by inserting the $-\sigma \iota$ and that many errors are still being committed throughout Herodotus' history as well as in Thucydides, Philistus, and other prominent historians. Why, then, should it not also happen that virtually all poetry is full of errors of transcription and other blundering (attempts at) correction, which are perfectly insensitive?».

(Philemon continues:) «Let us return to Herodotus and his editor, Alexander of Kotiaion. The learned gentleman thought it fit to write $\tau \hat{\eta} \sigma \mathrm{l} M \iota \lambda \eta \sigma^{\prime} \omega \nu$, without the iota, $\tau \hat{\eta} \varsigma \mathrm{M} \iota \lambda \eta \sigma^{\prime} \omega \nu$, with $\chi \boldsymbol{\omega}^{\prime} p \eta \varsigma$ or $\gamma \hat{\eta} \varsigma$ (i.e., 'region' or 'land') understood. And I», he says, «was persuaded that his reading was correct, and I admired the learned man for his keen intelligence. However, I happened upon these same Herodotean words at the end of the book on Egypt, which is the second book (159), and again I find Herodotus using them in the accusative case: 'Branchidai $\tau \dot{\alpha} \varsigma$ of the Milesians.' I no longer thought that it was a spelling error but rather that it was an Ionic idiom. (The Ionians) are fond of expressing many nouns in the feminine, such as 'stone,' 'column,' and even 'Marathon:' Cratinus: 'Marathon, most famed for (her) horses;' and Nicander: 'well-built(f.) Marathon.' This, then, is what we have discovered and we have judged it sound». Such were the words of Philemon, but I do not judge it appropriate for the present discussion to examine closely what he said against Alexander concerning the correction in Herodotus' (transl. Schlunk 1993, 31 and 33).

In his $\Sigma u ́ \mu \mu \varkappa \tau \alpha-$ a sort of collection of critical adversaria dedicated, entirely or in part, to the diorthosis of Herodotus' Histories - Philemon defended the paradosis of a Herodotean passage (I 92, 2), that had been questioned by Alexander. It should be stressed that the Atticist, in a work expressly dedicated to textual problems in the Histories, qualifies Alexander as $\theta \varepsilon p \alpha \pi \varepsilon \dot{\omega} \omega \nu$ of Herodotus' passage and then tout court as $\delta \delta 10 p \theta \omega \tau \eta \dot{s}$ (in the accusative). Philemon reports that in the Herodotean expression $\dot{\varepsilon} \nu$ Bparxion considered unacceptable the use of the feminine gender for Bparxioal and thought that the article $\tau \hat{\eta} \sigma \mathrm{l}$ was a corruption ( $ү р \alpha \varphi$ ixò $\dot{\alpha} \mu \dot{\alpha} \rho \tau \eta \eta \alpha)$; therefore

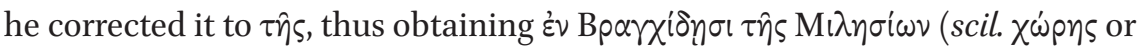
$\gamma \hat{\eta}$ ). Philemon admitted that at first he had the same perplexity, until he found another passage of the Histories, within the Egyptian logos, where Bpar $\chi^{i \delta} \alpha \mathrm{l}$ is

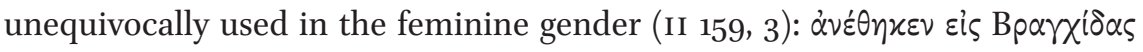
$\tau \dot{\alpha} \varsigma \mathrm{M} \iota \lambda \eta \sigma^{\prime} \omega \nu$. Philemon observed that in this case the espression is $x \alpha \tau \dot{\alpha} \tau \dot{\eta} \nu$ 
$\alpha i \tau \mid \alpha \tau i x \eta \nu \pi \tau \hat{\eta} \sigma \tau \nu$, 'in the accusative', clearly meaning that the article $\tau \dot{\alpha} \varsigma$ is free from phonic and graphic ambiguities which, on the contrary, can act in the manuscript transmission of forms like the genitive singular $\tau \hat{\eta} \varsigma$ and the Ionic dative plural $\tau \hat{\eta} \sigma$; and therefore that in this case it is not possibile to identify a plausible origin of textual corruption and the feminine article $\tau \dot{\alpha} s$ is to be undoubtedly considered as the correct reading. The passage from the second book of the Histories clearly supports the genuineness of the reading $\tau \eta \hat{\sigma} \sigma$ in the first book. Philemon justifies this linguistic behaviour of Herodotus

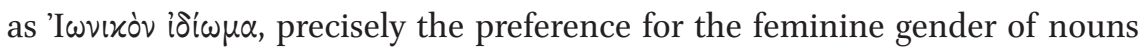

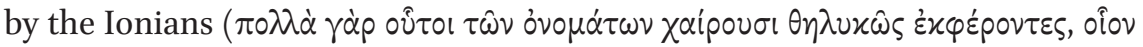

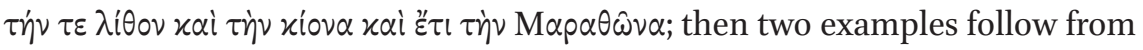
Cratinus and Nicander).

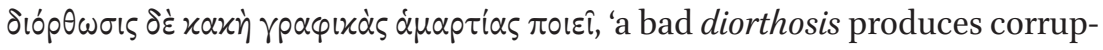
tions'. This lapidary sentence can be read in a writing transmitted in P.Herc. 1012 (col. XxI 3-4), probably a work by Demetrius Lacon, in a point where a passage of the sixth book of Hippocrates' Epidemics (VI 5, 15) is discussed. We can wonder whether Philemon knew this sentence, and if he remembered it when he decided to refuse Alexander's correction in Histories I 92, 2. The malignant irony of the gnome resides in indicating paradoxically as an effect of bad diorthosis the same thing that the diorthosis claims to cure, namely the rpapixai a $\mu \alpha p \tau i \alpha$. This is precisely the case of Alexander, in the eyes of Philemon and according to his words reported by Porphyry.

Unfortunately we are not able to determine the exact context, character and extension of Alexander's diorthotic activity on the Histories. This does not prevent, however, from getting some concluding remarks from this ancient technical discussion on a circumscribed textual problem. The episod documents first of all, in rather detailed manner, that the diorthosis was an integral part of the practice of reading and comment on literary texts usually performed by Alexander. It confirms what had been generically said by Aelius Aristides in his overview of the professional activity of his teacher, when in the funeral epistle

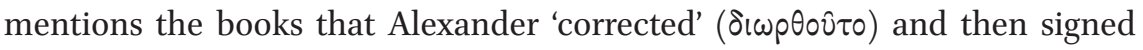
with his own name and with that of his homeland (Or. 32, 21).

Secondly, thanks to this example reported by Porphyry, we get some information on the history of the literary culture during the Antonine age, and more specifically on the areas in which were probably engaged at least some of the teachers of literature at that time, between educational practice and philological debate. On the one hand, issues of literary dialectology: in the case under examination, defining the linguistic and lexical correcteness of Ionic; on the other hand, the doubts on the genuineness of the vulgate text of the works of the canon, which obliged to take into account the errors of the manuscript 
transmission, so that the most cultivated, or audacious and reckless teachers were induced to make diorthotic interventions on a text. The case under study shows that these actions, though appearing bold and extemporaneous, on the contrary were based on the conscious need for an informed and well supported foundation - in other words, for a 'method'. Alexander was convinced of the presence of a textual corruption because of a linguistic behaviour (Bparxí $\delta$ l used in the feminine) that probably appeared to him dubious whenever he read and commented on that passage of Herodotus with his disciples; so he decided to 'cure' the presumed error in his personal copy of the Histories, on the basis of a philological reasoning, that is, the most advantageous reconstruction

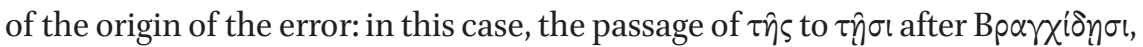
by homeoteleuton. We should wonder whether this specific case presupposes a higher level of critical awareness: supposing that in Herodotus a genuine Attic form was corrupted to a Ionic form implies knowing and admitting the possibility - in fact envisaged and debated in modern studies - of a hyperIonisation of the textual facies of the Histories in the manuscript tradition.

Finally, another significant implication of Porphyry's testimony resides in the association made between Homeric and Herodotean scholarship. The status of the vulgate of Herodotus at the time of Alexander and Philemon, and the resulting discussions, are proposed by Porphyry as examples of the situation that was equally observed for the Homeric text. Porphyry informs that the parallel had already been established by Philemon, but in an opposite direction: referring to Homeric textual problems in the field of Herodotean scholar-

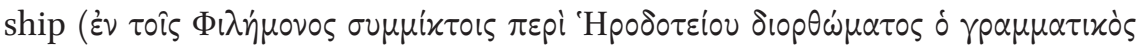

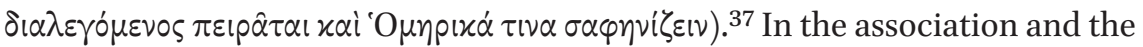
osmosis of these two areas of ancient philology we find reused and adapted the Hellenistic topos of the Homeric character of Herodotus' work. ${ }^{38}$ The eminent archetype of this method, consisting in explaining Homer through Herodotus and vice versa, is 'the best of the grammarians' Aristarchus, the

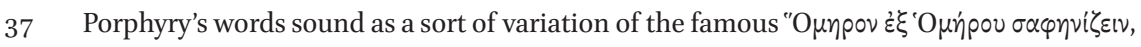
transmitted by himself ( $q$ h I 11, p. 297, 16 Schrader = p. 56, 3-4 Sodano; cf. the incipit of the prefatory epistle to book I addressed to Anatolius, p. 281, 2-3 Schrader = p. 1, 12-14 Sodano), which for the concept, if not even for the expression, dates back to Aristarchus (cf. Pfeiffer 1968, 225-227; Wilson 1971; Porter 1992, 70-85; Montanari 1997, 285-286; MacPhail 2011, 3-4).

38 Subl. 13.3. In the inscription from Halicarnassus (2nd/1st century вС) edited by Isager 1998,

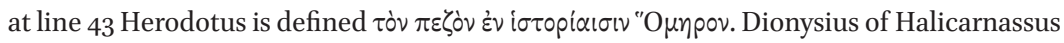
(Pomp. 3) states that Herodotus composed his work in a varied way, because he was an

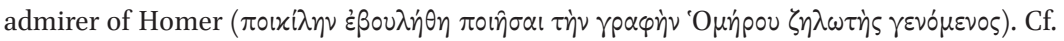
Pfeiffer 1968, 224; Boedeker 2002; Isager-Pedersen 2004. More bibliography in Montana 2018b, 17-18 n. 4 . 
greatest Homerist of the antiquity and author of the most ancient commentary known to us on a literary work in prose, the hypomnema to the first book of the Histories. The surviving fragment (P.Amh. II 12, of the 3rd century AD) brings evidence of the use of an epic-Homeric parallel to illustrate a military habit of the Massagetae reported by Herodotus (I 215, 1). ${ }^{39}$ Perhaps it is not by chance that the study of the Homeric lexicon and the diorthosis of the Histories stand out jointly as the two qualifying fields in what has been transmitted of Alexander's professional curriculum and writings. ${ }^{40}$

\section{Bibliography}

Alpers, K. (1998). Lexicographica Minora. In: C. F. Collatz (ed.), Dissertatiunculae criticae. Festschrift für Günther Christian Hansen, Würzburg, pp. 93-108.

Behr, Ch. A. (1968). Aelius Aristides and The sacred tales. Amsterdam.

Behr, Ch. A. (1981-1986). P. Aelius Aristides, The Complete Works translated into English, I-II. Leiden.

Berardi, E. (2002). Creso, Solone e Alessandro di Cotieo (Elio Aristide, Epitafio per Alessandro, 32, 28; Erodoto 1, 32, 8-9). Quaderni del Dipartimento di filologia linguistica e tradizione classica 19 , pp. 225-235.

Berardi, E. (2013). Migliori dei padri: modelli di giovani retori in Elio Aristide. Rhetorica 31, pp. 388-401.

Berardi, E. (2016). Maestri di Atticismo: la lingua e i suoi modelli in tre testi di ambiente scolastico di Elio Aristide (or. 30-32). In: L. Pernot, G. Abbamonte e M. Lamagna (edd.), M. C. Alvino (assist.), Aelius Aristide écrivain, Turnhout, pp. 245-262.

Boedeker, D. (2002). Epic Heritage and Mythical Patterns in Herodotus. In: E. G. Bakker, I. J. F. de Jong and H. van Wees (eds.), Brill's Companion to Herodotus, Leiden-Boston, pp. $97-116$.

Boulanger, A. (1923). Aelius Aristide et la Sophistique dans la province d'Asie au II' siècle de notre ère. Paris.

Chantraine, P. (1958). Grammaire homérique, I: Phonétique et morphologie. Paris.

Cohn, L. (1898). Der Attizist Philemon. Philologus 57, pp. 353-367.

Cortés Copete, J. M. (1995). Elio Aristides. Un sofista griego en el Imperio Romano. Madrid.

39 A new critical edition of the hypomnema, with commentary, in Montana 2018b, 39-61 (Herodotus 4 CLGP). It is possible to trace back to Aristarchus other associations between Homeric and Herodotean languages reported in some vM K-scholia to the Iliad: Montana 2016, 543-546.

40 Erbse 196o, 53-54, is skeptical about the connection. But cf. Montana 2018b, 18 n. 17 . 
Dain, A., ed. (1954). Le Philétaeros attribué à Hérodien. Paris.

Dyck, A. R. (1991). The Fragments of Alexander of Cotiaeum. ICs 16, pp. 307-335.

Dyck, A. R. (1993). Aelius Herodian. Recent Studies and Prospects for Future Research. ANRW II 34.1, Berlin-New York, pp. 772-794.

Erbse, H. (1960). Beiträge zur Überlieferung der Iliasscholien. München.

Isager, S. (1998). The Pride of Halicarnassos. Editio princeps of an Inscription from Salmakis. ZPE 123, pp. 1-23.

Isager, S. and Pedersen, P.(2004). The Salmakis Inscription and Hellenistic Halikarnassos. Odense.

Janko, R. (1991). The Iliad: a Commentary. Volume IV: Books 13-16. Cambridge.

Lehrs, K. (1837). Quaestiones epicae. Königsberg.

LGGA - F. Montanari, F. Montana and L. Pagani (eds.), Lexicon of Greek Grammarians of Antiquity: http://referenceworks.brillonline.com/browse/lexicon-of-greek -grammarians-of-antiquity.

MacPhail, J. A., ed. (2011). Porphyry's 'Homeric Questions' on the Iliad. Berlin-New York. Matthaios, S. (2015). Greek Scholarship in the Imperial Era and Late Antiquity. In: F. Montanari, S. Matthaios and A. Rengakos (eds.), Brill's Companion to Ancient Greek Scholarship, Leiden-Boston, I, pp. 184-296.

Meliadò, C. (2018). Basilides, in LGGA (1st ed. 2005).

Meliadò, C. (forthcoming). Cratinus, in $L G G A$ (forthcoming).

Montana, F. (2015). Hellenistic Scholarship. In: F. Montanari, S. Matthaios and A. Rengakos (eds.), Brill's Companion to Ancient Greek Scholarship, Leiden-Boston, I, pp. 6o-183.

Montana, F. (2016). Aristarco, Erodoto, l'Egitto: una nota. In: A. Casanova, G. Messeri e R. Pintaudi (a cura di), "e si d'amici pieno". Omaggio di studiosi italiani a Guido Bastianini per il suo settantesimo compleanno, Firenze, II, pp. 539-546.

Montana, F. (2018a). Alexander [6] Cotiaeus, in LGGA (1st ed. 2005).

Montana, F., ed. (2018b). Herodotus. In: G. Bastianini, D. Colomo, M. Haslam, H. Maehler, F. Montana, F. Montanari and C. Römer (eds.), Commentaria et lexica Graeca in papyris reperta. I 2, 6, Galenus-Hipponax, Berlin-Boston.

Montanari, F. (1996). Alexandros (n. 32). In: H. Cancik und H. Schneider (eds.), Der neue Pauly. Enzyklopädie der Antike, 1, Stuttgart-Weimar, p. 485.

Montanari, F. (1997). Fragments of Hellenistic Scholarship. In: G. W. Most (ed.), Collecting Fragments - Fragmente sammeln, Göttingen, pp. 273-288.

Naechster, M. (1908). De Pollucis et Phrynichi controversiis, Diss. Leipzig.

Pernot, L. (2008). Aspetti trascurati dell'educazione retorica nel II secolo d.C.: intorno ai maestri di Marco Aurelio. In: F. Gasti e E. Romano (edd.), Retorica ed educazione delle élites nell'antica Roma. Atti della vi giornata ghisleriana di filologia classica (Pavia, 4-5 aprile 2006), Como, pp. 95-111. 
Pfeiffer, R. (1968). History of Classical Scholarship. From the Beginnings to the End of the Hellenistic Age. Oxford.

Porter, J. I. (1992). Hermeneutic Lines and Circles: Aristarchus and Crates on the Exegesis of Homer. In: R. Lamberton and J. J. Keaney (eds.), Homer's Ancient Readers. The Hermeneutics of Greek Epic's Earliest Exegetes, Princeton, pp. 67-114.

Premerstein, A. von (1909). Die Urkunde eines arkadischen Synoikismos. Mitteilungen des Deutschen Archäologischen Instituts. Athenische Abteilung 34, pp. 237-268.

Reitzenstein, R. (1897). Geschichte der griechischen Etymologika. Ein Beitrag zur Geschichte der Philologie in Alexandria und Byzanz. Leipzig (repr. Amsterdam 1964). Sandys, J. E. $\left(1921^{3}\right)$. A History of Classical Scholarship. 1, From the Sixth Century B.C. to the End of the Middle Ages. Cambridge (1st ed. 1903).

Schlunk, R. R., transl. (1993). Porphyry, The Homeric Questions, A Bilingual Edition Translated by R. R. Schlunk. New York.

Schulze, W. (1934). Kleine Schriften. Göttingen.

Schwyzer, E. (1939). Griechische Grammatik, I, München.

Tosi, R. (1984). Prospettive e metodologie lessicografiche (a proposito delle recenti edizioni di Oro e Fozio). RSBS 4, pp. 181-203.

Ucciardello, G. (2007). Philemon [3], in LGGA (new edition forthcoming).

Valk, M. van der (1963-1964). Researches on the Text and Scholia of the Iliad, I-II. Leiden.

Vix, J.-L. (2004). L'analyse des textes: l'exemple du grammairien Alexandros de Cotiaeon (I ${ }^{\mathrm{e}}$ siècle après J.-C.). In: G. Abbamonte, F. Conti Bizzarro e L. Spina (edd.), L'ultima parola. L'analisi dei testi: teorie e pratiche nell'antichità greca e latina. Atti del terzo Colloquio italo-francese coordinato da L. Spina e L. Pernot, Napoli 13-15 marzo 2003, Napoli, pp. 361-372.

Vix, J.-L. (2010). L'enseignement de la rhétorique au II' siècle ap. J.-C. à travers les discours 30-34 d'Aelius Aristide. Turhout.

Wackernagel, J. (1878). Die epische Zerdehnung. Beiträge zur Kunde der indogerm. Sprachen 4, pp. 259-312. (repr. in: Kleine Schriften, II I, Göttingen 1979, pp. 1512-1565). Wackernagel, J. (1897). Vermischte Beiträge zur griechischen Sprachkunde. Basel (repr. in: Kleine Schriften, I, Göttingen 1953, pp. 764-823).

Wackernagel, J. (1916). Sprachliche Untersuchungen zu Homer. Göttingen.

Wentzel, G. (1894). Alexandros (n. 95), in A. Pauly, Paulys Realencyclopädie der classischen Altertumswissenschaft, neue Bearbeitung begonnen von G. Wissowa, unter Mitwirkung zahlreicher Fachgenossen hrsg. von W. Kroll, K. Mittelhaus und K. Ziegler, 1.2. Stuttgart, coll. $1455^{-1456 .}$

West, M. L., ed. (2000). Homeri Ilias, recensuit, testimonia congessit M. L. West, II, Stuttgart-Leipzig.

Wilson, N. W. (1971). An Aristarchean Maxim. $C R$ n.s. 21, p. 172. 